\title{
KAJIAN GEOLOGI, RADIOMETRI, DAN GEOKIMIA GRANIT BANGGAI DAN FORMASI BOBONG UNTUK MENENTUKAN DAERAH POTENSIAL URANIUM DI PULAU TALIABU, MALUKU UTARA
}

\section{GEOLOGICAL, RADIOMETRICAL, AND GEOCHEMICHAL STUDIES OF BANGGAI GRANITES AND BOBONG FORMATION TO DETERMINE POTENTIAL URANIUM AREA IN TALIABU ISLAND, NORTH MALUKU}

\author{
Ngadenin \\ Pusat Teknologi Bahan Galian Nuklir - BATAN, Jalan Lebak Bulus Raya No. 9, Jakarta 12440 \\ E-mail: ngadenin@batan.go.id
}

Naskah diterima: 15 April 2016, direvisi: 25 Mei 2016, disetujui: 27 Mei 2016

\begin{abstract}
ABSTRAK
Kajian geologi, radiometri, dan geokimia granit Banggai dan Formasi Bobong telah dilakukan untuk mendapatkan daerah potensial uranium. Pulau Taliabu dipilih sebagai lokasi kajian karena secara tektonik Pulau Taliabu adalah benua mikro pecahan dari benua Gondwana yang terpisah pada akhir Mesozoikum hingga Paleogen. Beberapa tipe mineralisasi uranium terbentuk pada periode Gondwana antara lain adalah mineralisasi tipe batupasir, mineralisasi tipe batubara lignit, dan mineralisasi tipe urat. Pulau Taliabu merupakan serpihan dari benua Gondwana sehingga diharapkan di Pulau Taliabu akan ditemukan mineralisasi uranium atau paling tidak ditemukan indikasi keterdapatan mineralisasi uranium. Tujuan dari kajian ini adalah untuk mendapatkan lokasi potensial uranium untuk pengembangan eksplorasi uranium di masa mendatang. Metode yang digunakan adalah mengkaji data geologi, radiometri, dan geokimia yang berasal dari berbagai sumber. Hasil kajian menunjukkan bahwa data geologi, radiometri, dan geokimia memberikan indikasi positif terhadap pembentukan cebakan uranium tipe batupasir. Granit Banggai berpotensi sebagai sumber uranium. Batupasir pada Formasi Bobong berpotensi sebagai batuan induk. Lapisan batubara dan pirit berpotensi sebagai presipitan. Daerah potensial uranium terletak di Formasi Bobong dan sekitarnya.
\end{abstract}

Kata kunci: Gondwana, benua mikro, geologi, uranium, Taliabu

\begin{abstract}
Geological, radiometrical, and geochemichal studies of Banggai granites and Bobong Formation have been conducted in order to obtain potential uranium area. Taliabu Island is selected for the study because Taliabu Island is a micro continent fraction of the Gondwana super continent that separated at the end of the Mesozoic to Paleogene period. Some types of uranium mineralization formed in the period of Gondwana include sandstonetype, lignite coal type, and vein-type. Taliabu Island is a small part from the Gondwana super continent so it is expected will be found uranium mineralization or at least indications of uranium mineralization occurences. The aim of this study is to obtain uranium potential areas for the development of uranium exploration in the future. The methods used are reviewing geological, radiometric, and geochemical data from various sources. The results of review showed that geological setting, radiometric, and geochemical data gives positive indication to the formation of uranium mineralization for sandstone type. Banggai granite is a potential uranium source. Sandstone of Bobong Formation as a potential host rock. Coal and pyrite as a potential precipitant. Uranium potential area is located on Bobong Formation and its surrounding.
\end{abstract}

Keywords: Gondwana, micro continent, geology, uranium, Taliabu 


\section{PENDAHULUAN}

Tipe mineralisasi uranium di Indonesia terdapat empat tipe, yaitu mineralisasi tipe batupasir yang terdapat pada batupasir Formasi Sibolga berumur Tersier di Kabupaten Tapanuli Tengah, Sumatera Utara [1]; mineralisasi tipe metamorphite yang terdapat pada batuan Malihan Pinoh berumur Yura-Trias di Kabupaten Melawi, Kalimantan Barat [2,3]; mineralisasi tipe volcanic related yang terdapat pada batuan gunung api Nyaan berumur Tersier di Kabupaten Mahakam Hulu, Kalimantan Timur [4-6] dan pada batuan gunung api Adang berumur Tersier di Kabupaten Mamuju, Sulawesi Barat [7]; serta mineralisasi tipe intrusive yang terdapat pada granit berumur Kapur di Kabupaten Lampung Tengah, Lampung [8]. Dalam rangka pengembangan eksplorasi uranium di Indonesia diperlukan penemuan lokasi-lokasi baru yang potensial terhadap pembentukan cebakan uranium. Pulau Taliabu dipilih sebagai lokasi kajian karena secara tektonik Pulau Taliabu merupakan micro continent pecahan dari super benua Gondwana (Gambar 1) [9-11] yang diperkirakan merupakan daerah potensial uranium seperti daerah potensial uranium di super benua Gondwana lainnya, yaitu di Afrika, Madagaskar, Amerika Selatan, India, dan Australia.

Gondwana merupakan super benua pecahan dari Pangea yang pada sekitar 200 juta tahun lalu terpecah menjadi dua, yaitu di bagian utara khatulistiwa disebut Laurasia dan di bagian selatan khatulistiwa disebut Gondwana. Gondwana adalah gabungan dari benua Amerika Selatan, Afrika, Arabia, Madagaskar, India, Australia, dan Antartika yang terbentuk pada jaman Prakambrium Akhir, sekitar 600 juta tahun yang lalu.
Benua-benua tersebut mulai terpisahkan pada periode Jura Awal, sekitar 180 juta tahun yang lalu (Gambar 2) [12,13]. Nama Gondwana diciptakan oleh ahli geologi Austria bernama Eduard Suess mengacu dari formasi batuan berumur Paleozoikum Awal (Kambrium Atas) hingga Mesozoikum (Yura Tengah) di wilayah Gondwana, India Tengah yang mirip dengan formasi batuan pada usia yang sama di benua belahan bumi selatan [14]. Cebakan uranium yang terbentuk pada periode Gondwana antara lain adalah cebakan uranium yang terdapat pada cekungan Karoo di Afrika [15], cekungan Gondwana di India [16], cekungan Amadeus di Australia [17], dan cekungan Parana di Amerika Selatan [18].

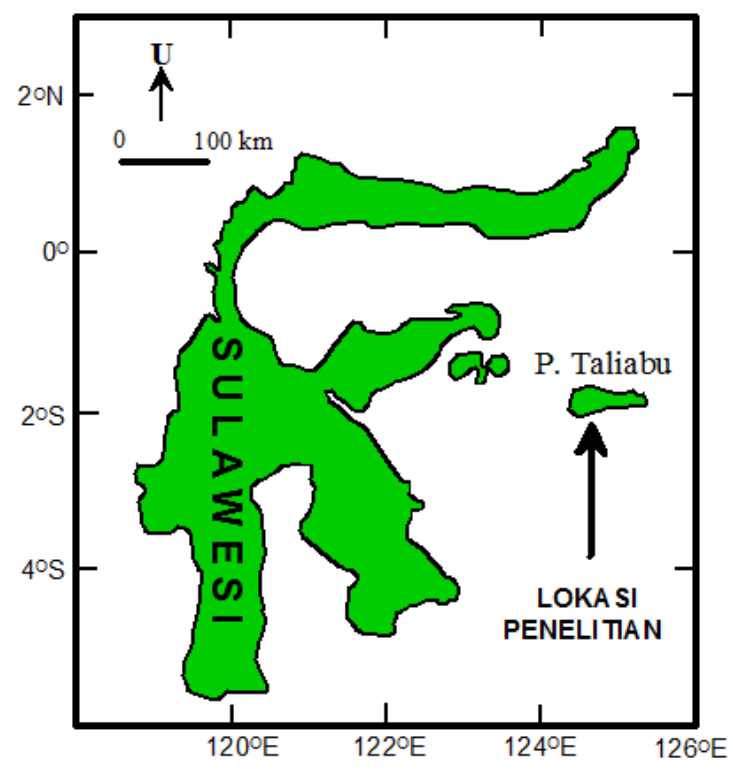

Gambar 1. Peta lokasi kajian.

Mineralisasi uranium yang terbentuk pada periode Gondwana terutama adalah mineralisasi tipe batupasir, mineralisasi tipe batubara lignit, dan mineralisasi tipe urat [1921]. Mineralisasi uranium tipe batupasir terbentuk pada batupasir yang diendapkan di lingkungan fluviatil dengan sumber uranium 
berasal dari batuan beku asam. Mineral utama yang terbentuk adalah pitchblende dan coffinite. Mineralisasi tipe batubara lignit terbentuk pada lapisan batubara atau lignit atau pada batulempung atau batupasir yang berbatasan langsung dengan lapisan batubara atau lignit. Kadar uranium biasanya sangat rendah (20-60 ppm) tetapi pada lapisan tersebut kadang terjadi pengayaan uranium hingga kadar meningkat mencapai sekitar 1000 ppm, sumber uranium umumnya berasal dari batuan beku asam. Mineralisasi tipe urat terbentuk pada urat-urat yang terdapat pada batuan beku asam, malihan, dan sedimen. Mineral utama yang terbentuk adalah pitchblende dan coffinite yang umumnya disertai dengan mineral gangue dan mineral hasil proses alterasi. Mineral penyerta yang terbentuk adalah pirit, markasit, kuarsa, hematit, karbonat, dan mineral logam dasar.

Susunan stratigrafi Pulau Taliabu ada yang mempunyai kemiripan dengan stratigrafi pada periode Gondwana, yaitu terdapatnya Formasi Bobong yang tersusun oleh breksi, konglomerat, batupasir, batulempung, batulumpur dengan sisipan serpih dan batubara serta nodul gipsum dan pirit yang diendapkan pada lingkungan fluviatil, transisi, hingga laut dangkal yang berumur Yura Awal-Yura Tengah dan kelompok granit Banggai yang tersusun oleh granit, granodiorit, diorit kuarsa, dan pegmatit berumur Trias [22-24] sehingga diharapkan di Pulau Taliabu akan diperoleh mineralisasi uranium seperti yang terdapat di Gondwana. Cebakan uranium yang berpotensi terbentuk di Pulau Taliabu adalah cebakan uranium tipe batupasir. Granit Banggai diperkirakan dapat berperan sebagai batuan sumber uranium dan Formasi Bobong berperan sebagai batuan induk. Tujuan dari kajian ini adalah untuk mendapatkan lokasi potensial uranium guna pengembangan eksplorasi uranium di masa mendatang. Metode yang digunakan adalah mengkaji data geologi, data radiometri, dan data geokimia yang berasal dari berbagai sumber.

\section{GEOLOGI PULAU TALIABU}

Secara umum morfologi Pulau Taliabu merupakan perbukitan bergelombang dengan ketinggian antara 0-1650 m di atas muka laut. Pola aliran sungai yang berkembang adalah dendritik hingga subparalel. Susunan starigrafi Pulau Taliabu dari batuan tertua ke yang termuda adalah komplek batuan malihan berumur Karbon, Formasi Menanga berumur Perem, batuan gunung api Mangole berumur Perem Akhir hingga Trias, granit Banggai berumur Perem Akhir hingga Trias, Formasi Bobong berumur Yura Awal hingga Yura Tengah, Formasi Buya berumur Yura akhir, Formasi Tanamu berumur Kapur, Formasi Salodik berumur Miosen, Formasi Peleng berumur Plistosen, dan aluvium berumur Holosen [22-24] (Gambar 2 dan 3). 
Kajian Geologi, Radiometri, dan Geokimia Granit Banggai dan Formasi Bobong untuk Menentukan Daerah Potensial Uranium di Pulau Taliabu, Maluku Utara

Oleh: Ngadenin

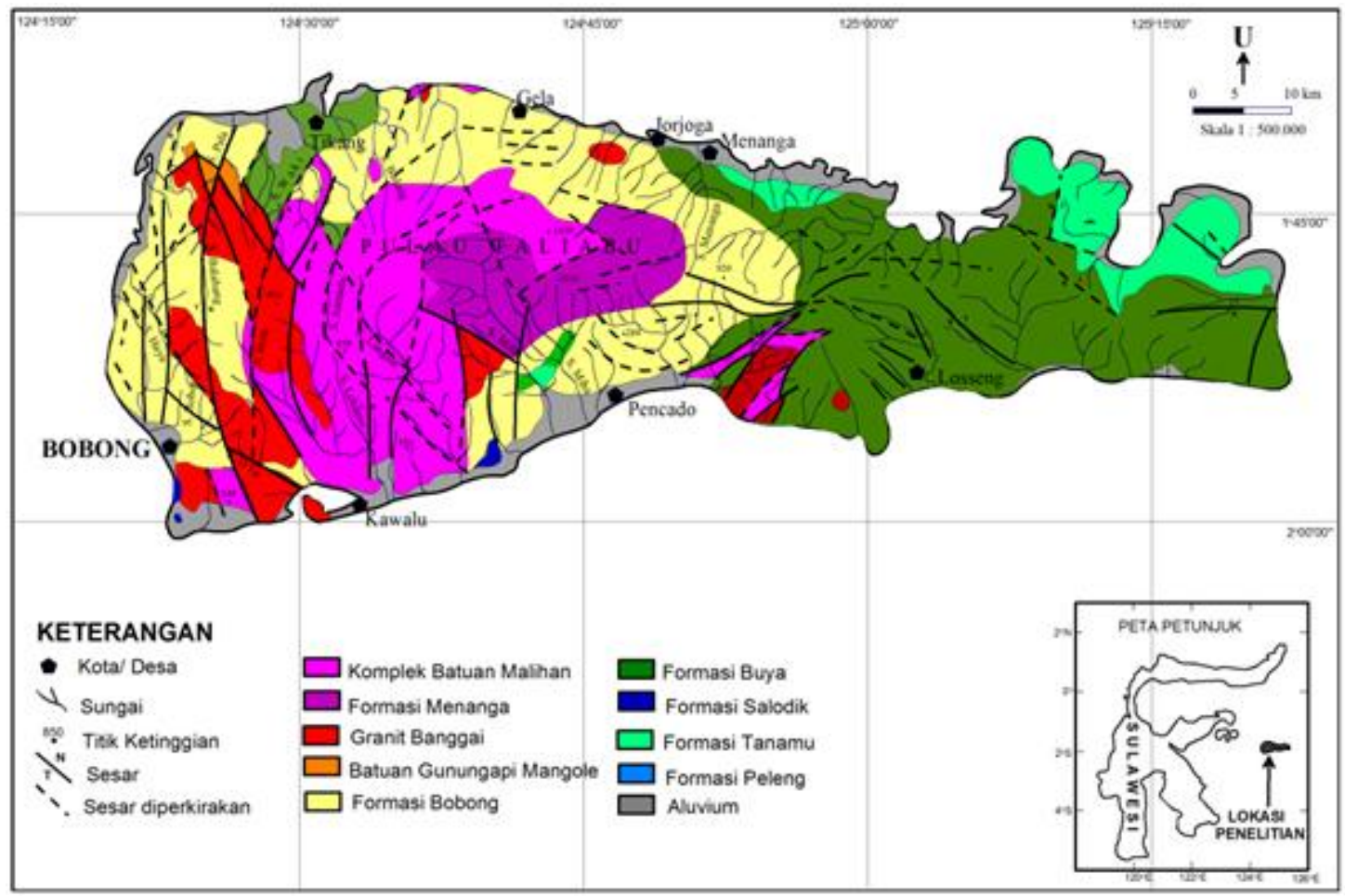

Gambar 2. Peta geologi Pulau Taliabu [22,23].

\begin{tabular}{|c|c|c|c|c|c|}
\hline & UMUR & $\begin{array}{c}\text { BATUAN } \\
\text { SEDIMEN/MALIHAN }\end{array}$ & PERIAN & \begin{tabular}{|l|} 
BATUAN \\
GUNUNGAP
\end{tabular} & $\begin{array}{l}\text { BATUAN } \\
\text { TEROBOSAN }\end{array}$ \\
\hline \multirow{2}{*}{ 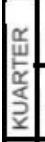 } & HOLOSEN & ALUVIUM & $\begin{array}{l}\text { Kerakal, kerikil, pasir, } \\
\text { lempung dan lumpur }\end{array}$ & & \\
\hline & PLISTOSEN & FORMASI PELENG & Batugamping Terumbu & & \\
\hline$\propto$ & 幽PLIOSEN & |||||| $\begin{array}{l}\text { Ketidak } \\
|||||||| \mid\end{array}$ & 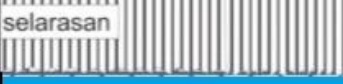 & & \\
\hline 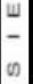 & 幽MIOSEN & FORMASI SALODIK & Batugamping dan Napal & & \\
\hline$\underline{q}$ & PALEOSEN & |||||||||||||| & sele & & \\
\hline \multirow{5}{*}{ 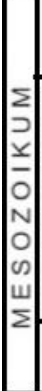 } & KAPUR & FORMASI TANAMU & $\begin{array}{c}\text { Napal, batugamping } \\
\text { kapuran, serpih }\end{array}$ & & \\
\hline & $\varangle$ AKHIR & $\begin{array}{c}\text { FORMASI } \\
\text { BUYA }\end{array}$ & $\begin{array}{c}\text { Serpih bersisipan batupasi } \\
\text { batugamping, napal dan } \\
\text { konglomerat }\end{array}$ & & \\
\hline & $\simeq$ TENGAH & & & & \\
\hline & \begin{tabular}{l|l} 
& \\
\cline { 2 - 2 } &
\end{tabular} & FORMASI BOBONG & $\begin{array}{l}\text { Breksi, konglomerat, batupasir } \\
\text { serpih, batulempung, batulumpur } \\
\text { dan batubara. }\end{array}$ & & \\
\hline & TRIAS & $\begin{array}{l}\text { BATUAN GUNUNG API } \\
\text { MANGOLE }\end{array}$ & $\begin{array}{c}\text { Tuf, tuf lapili, } \\
\text { breksi gunungapi }\end{array}$ & $\begin{array}{l}\text { vvvvvvv } \\
\text { v v v v v }\end{array}$ & $\begin{array}{l}\text { GRANI } \\
\text { BANGGAI }\end{array}$ \\
\hline \multirow[t]{2}{*}{ 空 } & PEREM & FORMASI MENANGA & $\begin{array}{l}\text { Perselingan batugamping hablur } \\
\text { batupasir malih, batusabak, filit }\end{array}$ & & \\
\hline & KARBON & $\begin{array}{l}\text { KOMPLEK } \\
\text { BATUAN MALIHAN }\end{array}$ & $\begin{array}{l}\text { Sekis, genes, amfibolit } \\
\text { dan kuarsit }\end{array}$ & & \\
\hline
\end{tabular}

Gambar 3. Kolom stratigrafi Pulau Taliabu [22-24]. 
Komplek batuan malihan merupakan batuan dasar di Pulau Taliabu, tersusun oleh sekis, genes, amfibolit, dan kuarsit dengan ketebalan diperkirakan lebih dari 1000 meter. Berdasarkan penentuan umur dengan metode radiometri dari contoh sekis, umur dari komplek batuan malihan adalah $305 \pm 6$ juta tahun atau setara dengan umur Karbon [25]. Secara tidak selaras di atas komplek batuan malihan diendapkan Formasi Menanga yang tersusun oleh perselingan antara batugamping hablur, batupasir malih, batusabak, dan filit. Ketebalan Formasi Menanga diperkirakan sekitar 1000 meter dan berumur Perem. Batuan gunung api Mangole yang terdiri dari tuf, tuf lapilli, dan breksi gunung api terbentuk pada Perem Akhir hingga Trias. Granit Banggai terdiri dari granit, granodiorit, diorirt kuarsa, dan pegmatit juga terbentuk pada Perem Akhir hingga Trias. Kelompok granit Banggai menerobos komplek batuan malihan dan Formasi Menanga. Indikasi proses hidrotermal seperti silisifikasi, kaolinisasi, dan propilitisasi pada granit ditemukan di beberapa tempat. Penentuan umur dengan metode radiometri dari contoh granit menunjukkan umur $235 \pm 10$ sampai dengan $245 \pm 25$ juta tahun $[25,26]$. Hasil penentuan umur dengan metode radiometri setara dengan umur Perem Akhir hingga Trias. Formasi Bobong yang tersusun oleh breksi, konglomerat, batupasir, batulempung, batulumpur dengan sisipan serpih, dan batubara serta nodul gypsum, dan pirit diendapkan tidak selaras di atas komplek batuan malihan. Formasi Bobong berumur Yura Awal-Yura Tengah dan diendapkan pada lingkungan fluviatil, transisi, hingga laut dangkal [27] dan mempunyai ketebalan sekitar 2000 meter, tersebar di bagian barat, utara, dan timur dari Pulau Taliabu serta telah mengalami pelipatan dengan kemiringan lapisan berkisar $20^{\circ}-30^{\circ}$. Formasi Buya yang tersusun oleh serpih bersisipan batupasir, batugamping, napal dan konglomerat yang berumur Yura Akhir diendapkan selaras di atas Formasi Bobong. Formasi ini diendapkan pada lingkungan transisi, laut dangkal, laut dalam, dan laut terbuka [28]. Formasi Tanamu berupa napal berwarna abu-abu kecoklatan dan berlapis baik dengan ketebalan sekitar 300 meter diendapkan tidak selaras di atas Formasi Buya pada jaman Kapur. Lingkungan pengendapannya pantai hingga laut dangkal. Formasi Salodik yang tersusun oleh perselingan batugamping dan napal kadang-kadang dijumpai sisipan batupasir dan batugamping terendapkan tidak selaras di atas Formasi Tanamu pada kala Miosen. Formasi Peleng yang tersusun oleh batugamping terumbu dan batugamping konglomeratan diendapkan tidak selaras di atas Formasi Salodik pada kala Plistosen. Batugamping terumbu tersusun oleh koral, moluska, dan ganggang. Satuan batuan termuda, yaitu pada kala Holosen diendapkan aluvium yang tersusun oleh lumpur, lempung, pasir, kerikil, dan kerakal yang belum terkonsolidasikan. Struktur geologi yang berkembang di Pulau Taliabu adalah sesar- sesar yang berarah utara-selatan, barattimur, barat laut-tenggara, dan timur lautbarat daya (Gambar 2).

\section{RADIOMETRI BATUAN}

Data radiometri batuan yang digunakan pada kajian ini adalah data radiometri batuan yang dianggap berpotensi terhadap terbentuknya cebakan uranium tipe batupasir di Pulau Taliabu. Data radiometri tersebut adalah data radiometri Formasi Bobong dan data radiometri granit Banggai hasil pengukuran penyelidikan terdahulu [29]. 


\section{Radiometri Formasi Bobong}

Pengukuran dilakukan di 24 lokasi. Radiometri terendah $50 \mathrm{c} / \mathrm{s}$ terdapat pada batulempung di lokasi pengukuran nomor 16, 17, dan 18 sedangkan radiometri tertinggi 200 $\mathrm{c} / \mathrm{s}$ terdapat pada batupasir di lokasi pengukuran nomor 13 (Tabel 1). Secara statistik, radiometri Formasi Bobong memiliki nilai rata-rata $(\mathrm{M})=96,88 \mathrm{c} / \mathrm{s}$, simpangan baku $(\mathrm{S})=34,35 \mathrm{c} / \mathrm{s}$, anomali $(\mathrm{M}$ $+2 \mathrm{~S})=165,58 \mathrm{c} / \mathrm{s}$. Satu lokasi anomali didapatkan dari data tersebut, yaitu batupasir di lokasi pengukuran nomor 13 dengan radiometri $200 \mathrm{c} / \mathrm{s}$ SPP2NF (Gambar 4).

Tabel 1. Radiometri Formasi Bobong.

\begin{tabular}{clc}
\hline $\begin{array}{c}\text { No. Lokasi } \\
\text { Pengukuran }\end{array}$ & \multicolumn{1}{c}{ Litologi } & $\begin{array}{c}\text { Radiometri } \\
\text { (c/s SPP2NF) }\end{array}$ \\
\hline 1 & Batupasir & 75 \\
2 & Batupasir & 120 \\
3 & Batupasir & 140 \\
4 & Batulempung & 125 \\
5 & Batupasir & 75 \\
6 & Serpih & 120 \\
7 & Batupasir & 100 \\
8 & Batupasir & 125 \\
9 & Batulempung & 80 \\
10 & Batupasir & 100 \\
11 & Batulempung & 130 \\
12 & Serpih & 120 \\
13 & Batupasir & 200 \\
14 & Batulempung & 100 \\
15 & Batulempung & 80 \\
16 & Batulempung & 50 \\
17 & Batupasir & 50 \\
18 & Batupasir & 50 \\
19 & Serpih & 100 \\
20 & Batupasir & 75 \\
21 & Batulempung & 75 \\
22 & Batulempung & 90 \\
23 & Batulempung & 70 \\
24 & Batulempung & 75 \\
\hline & & \\
\hline
\end{tabular}

\section{Radiometri Granit Banggai}

Pengukuran dilakukan di 21 lokasi. Radiometri terendah $100 \mathrm{c} / \mathrm{s}$ terdapat pada granit di lokasi pengukuran nomor 38 sedangkan radiometri tertinggi $1200 \mathrm{c} / \mathrm{s}$ dijumpai pada granit di lokasi pengukuran nomor 28 (Tabel 2). Secara statistik, pengukuran radiometri granit Banggai memiliki nilai rata-rata $(\mathrm{M})=265,48 \mathrm{c} / \mathrm{s}$, simpangan baku $(\mathrm{S})=107,67 \mathrm{c} / \mathrm{s}$, anomali $(\mathrm{M}$ $+2 \mathrm{~S})=480,81 \mathrm{c} / \mathrm{s}$. Satu lokasi anomali didapatkan dari data tersebut. yaitu granit dengan radiometri $1200 \mathrm{c} / \mathrm{s}$ yang terdapat di lokasi pengukuran nomor 28 (Gambar 4).

Tabel 2. Radiometri granit Banggai.

\begin{tabular}{clc}
\hline $\begin{array}{c}\text { No. Lokasi } \\
\text { Pengukuran }\end{array}$ & Litologi & $\begin{array}{c}\text { Radiometri } \\
\text { (c/s SPP2NF) }\end{array}$ \\
\hline 25 & Granit & 200 \\
26 & Granit & 250 \\
27 & Granit & 275 \\
28 & Granit & 1200 \\
29 & Granit & 350 \\
30 & Granit & 375 \\
31 & Granit & 300 \\
32 & Granit & 350 \\
33 & Granit & 350 \\
34 & Granit & 300 \\
35 & Granit & 200 \\
36 & Granit & 125 \\
37 & Granit & 200 \\
38 & Granit & 100 \\
39 & Granodiorit & 150 \\
40 & Granit & 300 \\
41 & Granit & 350 \\
42 & Granit & 350 \\
43 & Granit & 400 \\
44 & Granit & 250 \\
45 & Granit & 400 \\
\hline & &
\end{tabular}

\section{KADAR URANIUM}

Data kadar uranium yang digunakan untuk kajian ini adalah data kadar uranium batuan, data kadar uranium endapan sungai, dan konsentrat dulang. Data tersebut didapatkan dari hasil analisis penyelidikan terdahulu [29]. 


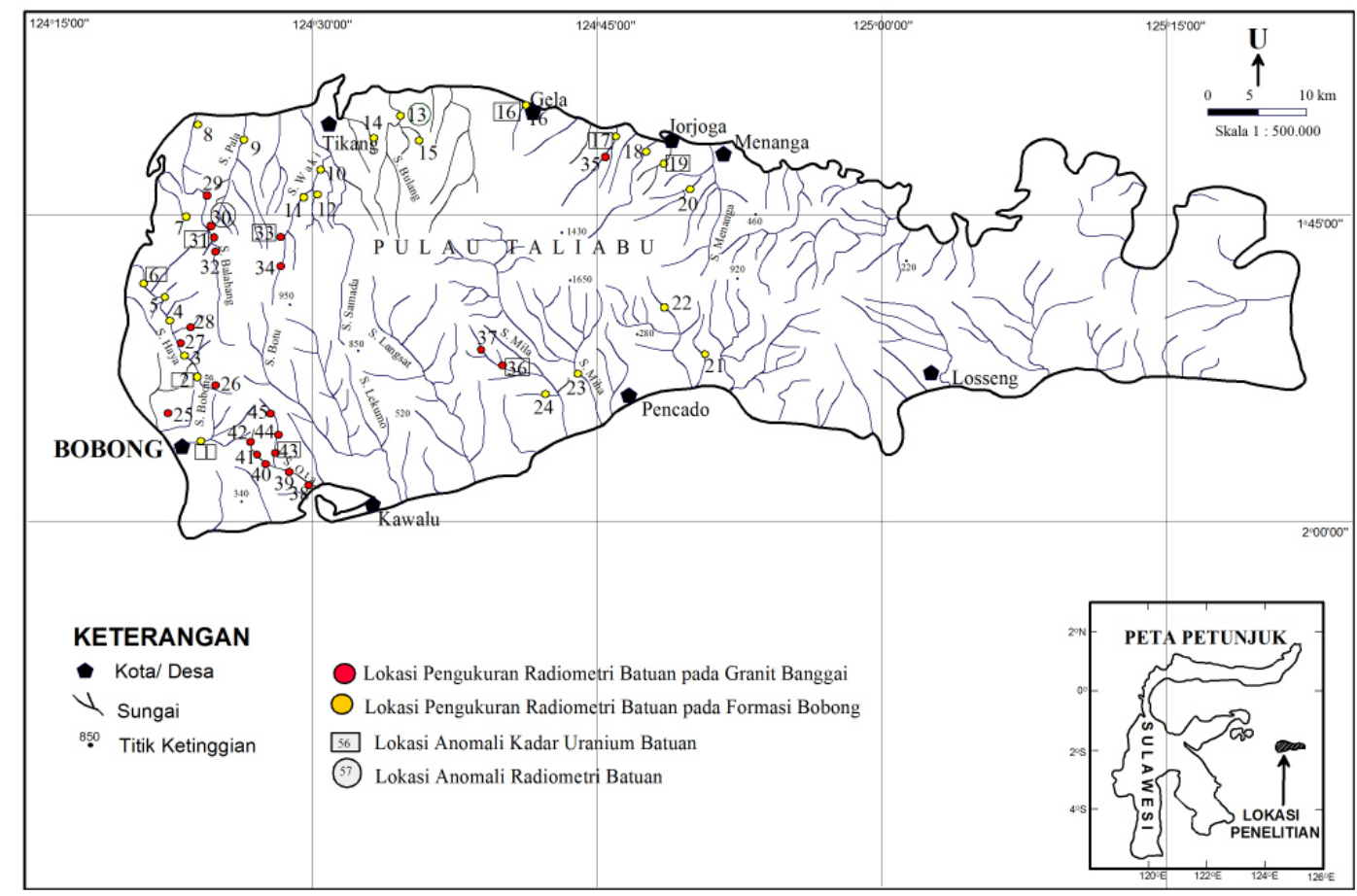

Gambar 4. Peta radiometri dan kadar uranium batuan Pulau Taliabu [29].

\section{Kadar Uranium Batuan}

Data kadar uranium yang digunakan adalah kadar uranium batuan yang dianggap berpotensi terhadap pembentukan cebakan uranium tipe batupasir, yaitu data kadar uranium batuan dari Formasi Bobong dan granit Banggai seperti yang tertera pada tabel 3 dan 4. Data kadar uranium Formasi Batuan lainnya tidak digunakan karena dianggap tidak berpotensi terhadap pembentukan cebakan uranium tipe batupasir. Jumlah data kadar uranium batuan Formasi Bobong adalah 10 sampel. Kadar uranium terendah 0,75 ppm terdapat pada batupasir sampel nomor 4 sedangkan kadar uranium tertinggi 13,26 ppm terdapat pada batupasir sampel nomor 17 (Tabel 3). Anomali kadar uranium batuan diasumsikan sebesar 2,5 kali dari kadar uranium latar dalam batuan terkait. Kadar uranium latar pada batupasir adalah 1,5 ppm [30] sehingga anomalinya adalah 2,5 $\mathrm{x} 1,5 \mathrm{ppm}=3,75 \mathrm{ppm}$. Lokasi anomali yang mengacu pada nilai anomali hasil perhitungan adalah lokasi nomor 1, 2, 6, 16, 17, dan 19 (Gambar 4).

Tabel 3. Kadar uranium Formasi Bobong.

\begin{tabular}{cclc}
\hline No. & $\begin{array}{c}\text { No. } \\
\text { Sampel }\end{array}$ & Litologi & $\begin{array}{c}\text { Kadar U } \\
\text { (ppm) }\end{array}$ \\
\hline 1 & 1 & Batupasir & 4,25 \\
2 & 2 & Batupasir & 7,44 \\
3 & 4 & Batupasir & 0,75 \\
4 & 6 & Batupasir & 10,6 \\
5 & 7 & Batupasir & 3,61 \\
6 & 8 & Batulempung & 3,41 \\
7 & 12 & Batupasir & 2,75 \\
8 & 16 & Batupasir & 4,52 \\
9 & 17 & Batupasir & 13,26 \\
10 & 19 & Batupasir & 9,23 \\
\hline
\end{tabular}

Jumlah data kadar uranium granit Banggai adalah 8 sampel. Kadar uranium terendah 2,93 ppm terdapat pada granit sampel nomor 28 sedangkan kadar uranium tertinggi 23,77 ppm terdapat pada granit sampel nomor 43 (Tabel 4). Anomali kadar uranium batuan diasumsikan sebesar 2,5 kali dari kadar uranium latar dalam batuan terkait. Kadar uranium latar pada granit adalah 4,5 ppm [30] sehingga anomalinya adalah $2,5 \mathrm{x}$ 
4,5 ppm $=11,25$ ppm. Lokasi anomali yang mengacu pada nilai anomali hasil perhitungan tersebut adalah lokasi nomor 31, 33, 36, dan 43 (Gambar 4).

Tabel 4. Kadar uranium granit Banggai.

\begin{tabular}{cccc}
\hline No & $\begin{array}{c}\text { No. } \\
\text { Sampel }\end{array}$ & Litologi & $\begin{array}{c}\text { Kadar U } \\
(\mathbf{p p m})\end{array}$ \\
\hline 1 & 28 & Granit & 2,93 \\
2 & 29 & Granit & 10,64 \\
3 & 31 & Granit & 18,54 \\
4 & 33 & Granit & 14,25 \\
5 & 35 & Granit & 3,72 \\
6 & 36 & Granit & 10,58 \\
7 & 37 & Granit & 9,69 \\
8 & 43 & Granit & 23,77 \\
\hline
\end{tabular}

\section{Kadar Uranium Endapan Sungai}

Data kadar uranium endapan sungai berjumlah 101 buah. Kadar uranium terendah 0,02 ppm dan tertinggi 18,31 ppm (Tabel 5). Secara statistik kadar uranium endapan sungai rata-rata $(\mathrm{M})=2,44 \mathrm{ppm}$, simpangan baku $(\mathrm{S})=3,05 \mathrm{ppm}$, anomali $(\mathrm{M}+2 \mathrm{~S})=8,54$ ppm. Delapan lokasi anomali didapatkan dari data tersebut (Gambar 5). Pola penyebaran anomali berarah utara-selatan terdapat di sekitar daerah aliran Sungai Mila, Sungai Botu, Sungai Ota, dan Sungai Waki (Gambar 6).

\section{Kadar Uranium Konsentrat Dulang}

Data kadar uranium konsentrat dulang berjumlah 70 buah. Kadar terendah 0,1 ppm dan tertinggi 1004,04 ppm (Tabel 6). Secara statistik kadar uranium konsentrat dulang rata-rata $(\mathrm{M})=205,72 \mathrm{ppm}$, simpangan baku $(\mathrm{S})=126,39 \mathrm{ppm}$, anomali $(\mathrm{M}+2 \mathrm{~S})=$ 458,49 ppm. Sepuluh lokasi anomali didapatkan dari data tersebut (Gambar 5). Pola penyebaran anomali relatif berarah utara-selatan, yaitu tersebar di sekitar daerah aliran Sungai Pala, Sungai Balahang, Sungai Bobong, dan Sungai Mila (Gambar 7).

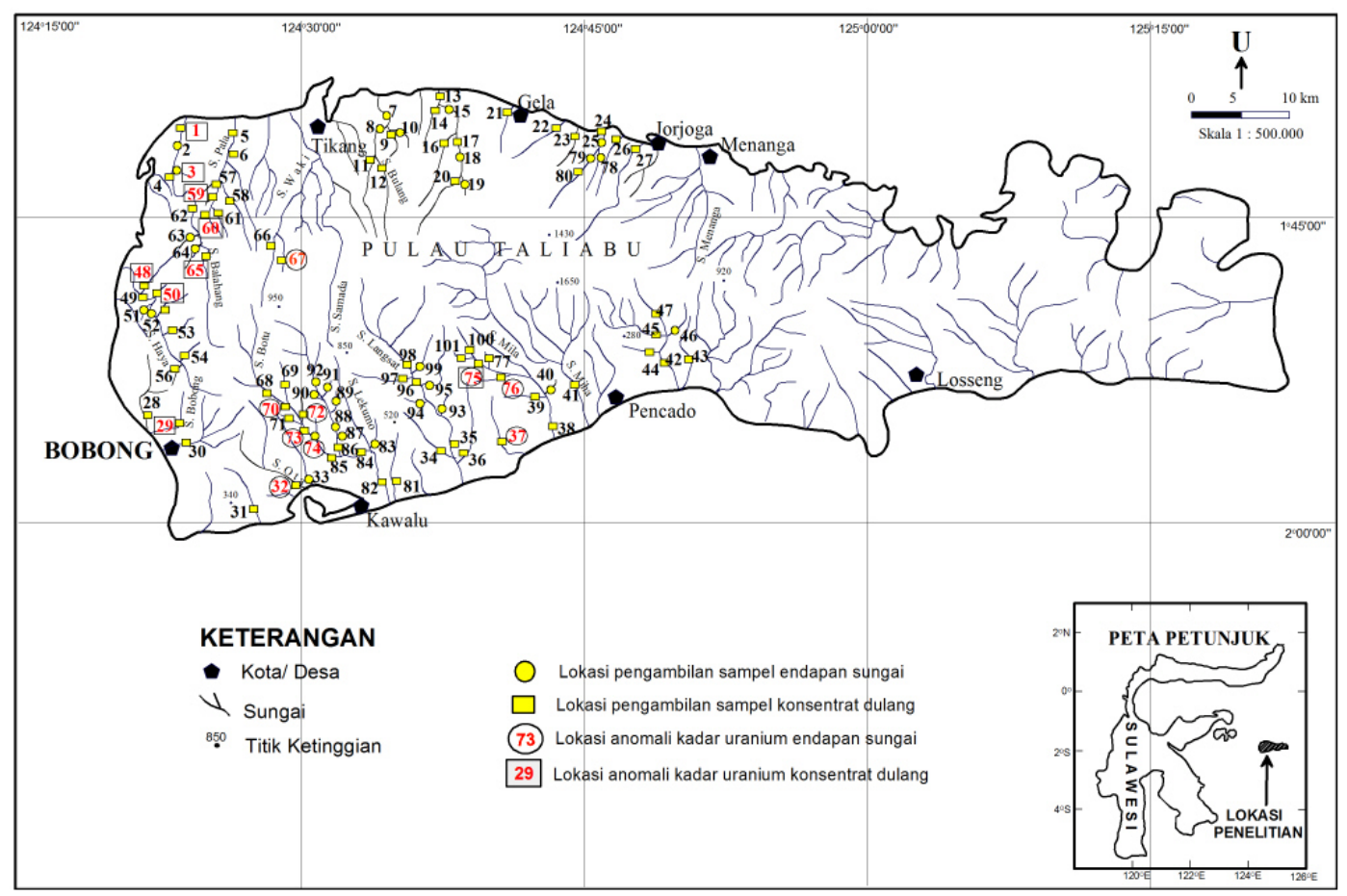

Gambar 5. Peta lokasi pengambilan sampel endapan sungai dan konsentrat dulang di Pulau Taliabu [29]. 
Tabel 5. Kadar uranium endapan sungai.

\begin{tabular}{|c|c|c|c|c|c|}
\hline $\begin{array}{c}\text { No. } \\
\text { Sampel }\end{array}$ & $\begin{array}{c}\text { Kadar U } \\
\text { Endapan } \\
\text { Sungai (ppm) }\end{array}$ & Formasi & $\begin{array}{c}\text { No. } \\
\text { Sampel }\end{array}$ & $\begin{array}{c}\text { Kadar U } \\
\text { Endapan } \\
\text { Sungai (ppm) }\end{array}$ & Formasi \\
\hline 1 & 5,7 & Bobong & 52 & 0,7 & Granit Banggai \\
\hline 2 & 1,94 & Bobong & 53 & 2,69 & Granit Banggai \\
\hline 3 & 1,5 & Bobong & 54 & 0,25 & Granit Banggai \\
\hline 4 & 2,2 & Bobong & 55 & 1,41 & Granit Banggai \\
\hline 5 & 3,66 & Bobong & 56 & 7,92 & Granit Banggai \\
\hline 6 & 2,78 & Bobong & 57 & 0,42 & Granit Banggai \\
\hline 7 & 0,16 & Bobong & 58 & 6,78 & Granit Banggai \\
\hline 8 & 0,27 & Bobong & 59 & 3,03 & Granit Banggai \\
\hline 9 & 0,19 & Bobong & 60 & 4,73 & Granit Banggai \\
\hline 10 & 0,48 & Bobong & 61 & 5,4 & Granit Banggai \\
\hline 11 & 0,26 & Bobong & 62 & 6,14 & Granit Banggai \\
\hline 12 & 0,29 & Bobong & 63 & 2,88 & Granit Banggai \\
\hline 13 & 0,24 & Bobong & 64 & 2,86 & Granit Banggai \\
\hline 14 & 0,28 & Bobong & 65 & 4,53 & Granit Banggai \\
\hline 15 & 0,26 & Bobong & 66 & 5 & Granit Banggai \\
\hline 16 & 0,23 & Bobong & 67 & 11,89 & Granit Banggai \\
\hline 17 & 0,27 & Bobong & 68 & 7,67 & Granit Banggai \\
\hline 18 & 0,33 & Bobong & 69 & 8,37 & Granit Banggai \\
\hline 19 & 0,23 & Bobong & 70 & 12,4 & Granit Banggai \\
\hline 20 & 0,18 & Bobong & 71 & 5,74 & Granit Banggai \\
\hline 21 & 0,53 & Bobong & 72 & 10,83 & Granit Banggai \\
\hline 22 & 0,9 & Bobong & 73 & 9,44 & Granit Banggai \\
\hline 23 & 0,48 & Bobong & 74 & 14,62 & Granit Banggai \\
\hline 24 & 0,63 & Bobong & 75 & 18,31 & Granit Banggai \\
\hline 25 & 0,38 & Bobong & 76 & 8,97 & Granit Banggai \\
\hline 26 & 0,35 & Bobong & 77 & 0,54 & Granit Banggai \\
\hline 27 & 0,65 & Bobong & 78 & 0,35 & Granit Banggai \\
\hline 28 & 0,54 & Bobong & 79 & 0,23 & Granit Banggai \\
\hline 29 & 1,38 & Bobong & 80 & 0,38 & Granit Banggai \\
\hline 30 & 0,43 & Bobong & 81 & 1,54 & Komplek Malihan \\
\hline 31 & 1,56 & Bobong & 82 & 3,2 & Komplek Malihan \\
\hline 32 & 11 & Bobong & 83 & 1,62 & Komplek Malihan \\
\hline 33 & 7,2 & Bobong & 84 & 4,76 & Komplek Malihan \\
\hline 34 & 0,11 & Bobong & 85 & 5,93 & Komplek Malihan \\
\hline 35 & 0,11 & Bobong & 86 & 1,3 & Komplek Malihan \\
\hline 36 & 6,48 & Bobong & 87 & 0,28 & Komplek Malihan \\
\hline 37 & 6,34 & Bobong & 88 & 3,65 & Komplek Malihan \\
\hline 38 & 5,95 & Bobong & 89 & 0,72 & Komplek Malihan \\
\hline 39 & 1,66 & Bobong & 90 & 0,68 & Komplek Malihan \\
\hline 40 & 3,95 & Bobong & 91 & 0,75 & Komplek Malihan \\
\hline 41 & 0,48 & Bobong & 92 & 2,35 & Komplek Malihan \\
\hline 42 & 2,15 & Bobong & 93 & 0,22 & Komplek Malihan \\
\hline 43 & 0,26 & Bobong & 94 & 0,18 & Komplek Malihan \\
\hline 44 & 0,1 & Bobong & 95 & 0,12 & Komplek Malihan \\
\hline 45 & 0,76 & Bobong & 96 & 0,37 & Komplek Malihan \\
\hline 46 & 0,1 & Bobong & 97 & 0,16 & Komplek Malihan \\
\hline 47 & 0,35 & Bobong & 98 & 0,3 & Komplek Malihan \\
\hline 48 & 3,18 & Granit Banggai & 99 & 0,25 & Komplek Malihan \\
\hline 49 & 3,1 & Granit Banggai & 100 & 1,5 & Komplek Malihan \\
\hline 50 & 2 & Granit Banggai & 101 & 0,29 & Komplek Malihan \\
\hline 51 & 0,02 & Granit Banggai & - & - & - \\
\hline
\end{tabular}




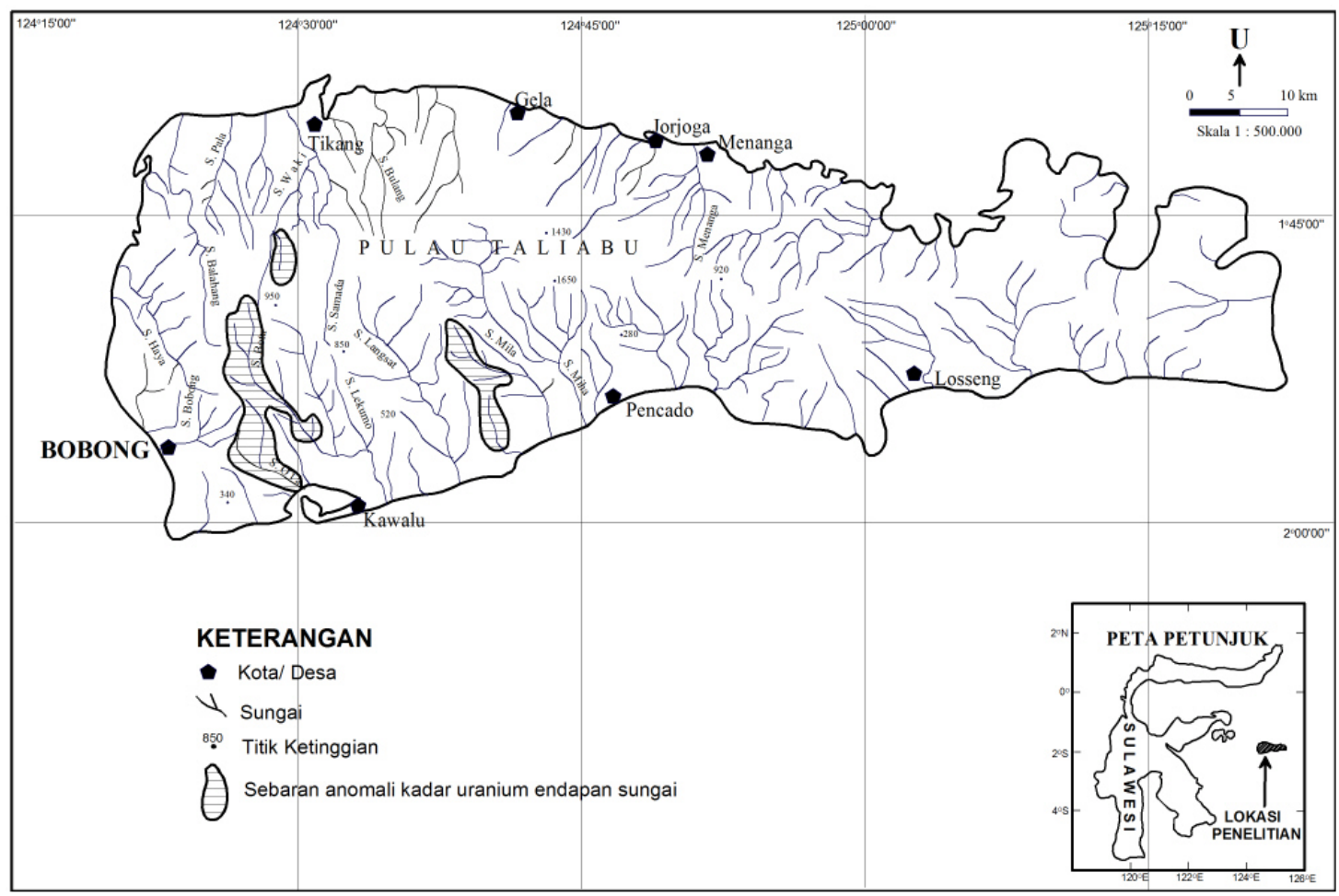

Gambar 6. Peta sebaran anomali kadar uranium endapan sungai.

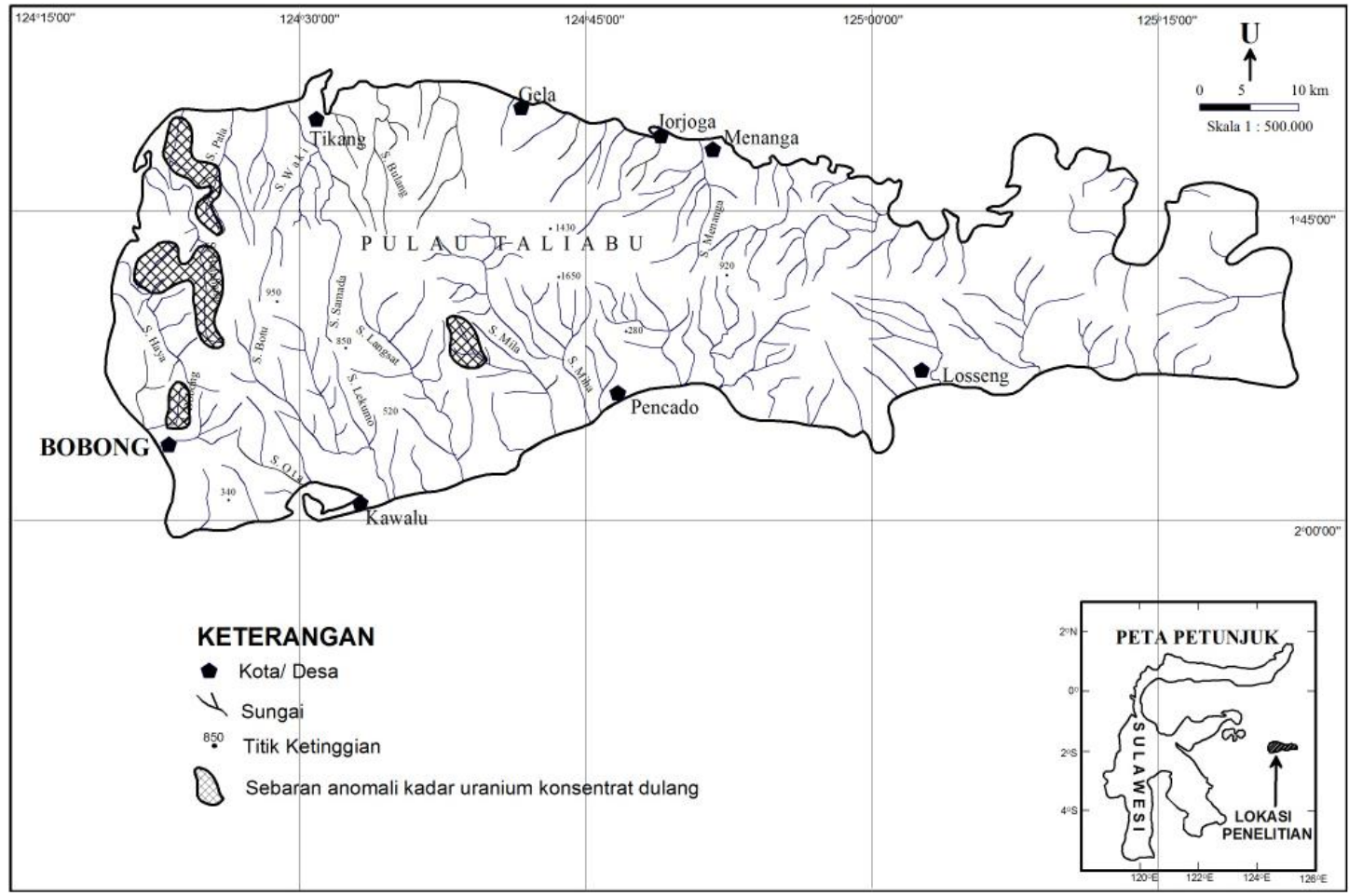

Gambar 7. Peta sebaran anomali kadar uranium konsentrat dulang. 
Tabel 6. Kadar uranium konsentrat dulang.

\begin{tabular}{|c|c|c|c|c|c|c|c|}
\hline No. & $\begin{array}{c}\text { No. } \\
\text { Sampel }\end{array}$ & $\begin{array}{c}\text { Kadar U } \\
\text { Konsentrat } \\
\text { Dulang (ppm) }\end{array}$ & Formasi & No. & $\begin{array}{c}\text { No. } \\
\text { Sampel }\end{array}$ & $\begin{array}{c}\text { Kadar U } \\
\text { Konsentrat } \\
\text { Dulang (ppm) }\end{array}$ & Formasi \\
\hline 1 & 1 & 960 & Bobong & 36 & 49 & 320 & Granit Banggai \\
\hline 2 & 3 & 700 & Bobong & 37 & 50 & 470 & Granit Banggai \\
\hline 3 & 5 & 64 & Bobong & 38 & 53 & 380 & Granit Banggai \\
\hline 4 & 6 & 160 & Bobong & 39 & 54 & 78 & Granit Banggai \\
\hline 5 & 9 & 1 & Bobong & 40 & 55 & 180 & Granit Banggai \\
\hline 6 & 11 & 12,4 & Bobong & 41 & 56 & 360 & Granit Banggai \\
\hline 7 & 12 & 0,9 & Bobong & 42 & 57 & 42 & Granit Banggai \\
\hline 8 & 13 & 0,7 & Bobong & 43 & 58 & 300 & Granit Banggai \\
\hline 9 & 14 & 2,2 & Bobong & 44 & 59 & 700 & Granit Banggai \\
\hline 10 & 16 & 3,9 & Bobong & 45 & 60 & 640 & Granit Banggai \\
\hline 11 & 17 & 3,6 & Bobong & 46 & 61 & 80 & Granit Banggai \\
\hline 12 & 20 & 1,4 & Bobong & 47 & 62 & 275 & Granit Banggai \\
\hline 13 & 21 & 2 & Bobong & 48 & 65 & 470 & Granit Banggai \\
\hline 14 & 22 & 1,7 & Bobong & 49 & 66 & 240 & Granit Banggai \\
\hline 15 & 23 & 1,5 & Bobong & 50 & 67 & 300 & Granit Banggai \\
\hline 16 & 24 & 2,5 & Bobong & 51 & 68 & 218,85 & Granit Banggai \\
\hline 17 & 26 & 2,7 & Bobong & 52 & 69 & 273,21 & Granit Banggai \\
\hline 18 & 27 & 2 & Bobong & 53 & 70 & 315,31 & Granit Banggai \\
\hline 19 & 28 & 260 & Bobong & 54 & 71 & 231,94 & Granit Banggai \\
\hline 20 & 29 & 760 & Bobong & 55 & 72 & 340,58 & Granit Banggai \\
\hline 21 & 30 & 7 & Bobong & 56 & 73 & 281,68 & Granit Banggai \\
\hline 22 & 31 & 91,23 & Bobong & 57 & 75 & 1004,64 & Granit Banggai \\
\hline 23 & 32 & 159,29 & Bobong & 58 & 76 & 329,53 & Granit Banggai \\
\hline 24 & 34 & 43,48 & Bobong & 59 & 77 & 1,89 & Granit Banggai \\
\hline 25 & 35 & 7,72 & Bobong & 60 & 80 & 1,8 & Granit Banggai \\
\hline 26 & 36 & 416,54 & Bobong & 61 & 81 & 139,01 & Komplek Malihan \\
\hline 27 & 37 & 856,96 & Bobong & 62 & 82 & 108,67 & Komplek Malihan \\
\hline 28 & 38 & 329,53 & Bobong & 63 & 84 & 139,29 & Komplek Malihan \\
\hline 29 & 39 & 234,59 & Bobong & 64 & 85 & 190,31 & Komplek Malihan \\
\hline 30 & 41 & 87,97 & Bobong & 65 & 86 & 147,51 & Komplek Malihan \\
\hline 31 & 42 & 73,26 & Bobong & 66 & 96 & 3,21 & Komplek Malihan \\
\hline 32 & 43 & 59,49 & Bobong & 67 & 97 & 3,32 & Komplek Malihan \\
\hline 33 & 44 & 33,12 & Bobong & 68 & 98 & 3,14 & Komplek Malihan \\
\hline 34 & 45 & 90,6 & Bobong & 69 & 100 & 108,01 & Komplek Malihan \\
\hline 35 & 48 & 940 & Granit Banggai & 70 & 101 & 0,1 & Komplek Malihan \\
\hline
\end{tabular}

\section{PEMBAHASAN}

Pengendapan batuan Formasi Bobong mempunyai kemiripan dengan periode pembentukan cekungan pada periode Gondwana. Periode pengendapan di cekungan Gondwana berkisar antara Kambrium Akhir hingga Yura Tengah sedangkan pengendapan batuan Formasi Bobong berkisar dari Yura Awal-Yura Tengah sehingga merupakan periode akhir Gondwana. Tipe mineralisasi uranium mengacu pada tatanan geologi Pulau Taliabu adalah mineralisasi tipe batupasir. Mineralisasi tipe batupasir berpotensi terbentuk karena di Pulau Taliabu terdapat granit Banggai berumur Trias dan Formasi Bobong yang tersusun oleh batuan sedimen klastik yang diendapkan pada lingkungan fluviatil, transisi, hingga laut dangkal dan berumur Yura Awal-Yura Tengah. Granit Banggai berpotensi sebagai sumber uranium dan Formasi Bobong berpotensi sebagai tempat terakumulasinya uranium. Pembentukan mineralisasi uranium tipe 
batupasir dipengaruhi oleh tiga faktor, yaitu sumber uranium, batuan induk yang mampu mengangkut larutan kaya uranium, dan presipitan. Sumber uranium dapat berasal dari larutan hidrotermal, tuf, dan batuan granitik. Batuan induk adalah batupasir berukuran pasir sedang-kasar (lanau-konglomeratan), berlapis-lentikular, diendapkan dalam sistem kipas aluvial, cekungan intermontane atau lingkungan laut tepi benua. Presipitan adalah agen yang mampu mereduksi uranium dari uranil ke uranous. Presipitan utama untuk mineralisasi uranium tipe batupasir adalah material karbon dan pirit [31].

Persyaratan granit dapat berperan sebagai sumber uranium adalah kadar uranium dalam granit cukup signifikan. Contoh mineralisasi uranium tipe batupasir di cekungan Mahadek, India dengan kadar uranium dalam granit sekitar 7-110 ppm dan granit sebagai sumber uranium [20]. Granit Banggai berkadar 23,77 ppm sehingga memenuhi kriteria sebagai batuan sumber uranium. Di samping itu, anomali kadar uranium endapan sungai (Gambar 6) dan anomali kadar uranium konsentrat dulang terdapat pada daerah di sekitar aliran sungai yang melewati granit Banggai (Gambar 7). Data anomali tersebut memberikan petunjuk bahwa terdapat uranium yang terlarut berasal dari granit Banggai. Dalam kondisi oksidasi, uranium bervalensi empat yang bersifat stabil berubah jadi uranium bervalensi enam yang bersifat mobile dan bila terkena air akan terlarut. Data bacaan radiometri granit Banggai ada yang mencapai $1200 \mathrm{c} / \mathrm{s}$, di daerah Sungai Mentawa, Kalimantan Tengah mineralisasi uranium di granit memiliki bacaan radiometri $500 \mathrm{c} / \mathrm{s}$ [32] sedangkan mineralisasi uranium pada granit di Lampung Tengah mempunyai bacaan radiometri 600 c/s [8].

Persyaratan batuan sedimen klastik berpotensi sebagai batuan induk uranium apabila batuan tersebut berupa batupasir berukuran pasir sedang-kasar yang diendapkan pada lingkungan darat. Batupasir Formasi Bobong berukuran pasir kasar dan diendapkan pada lingkungan darat [27] sehingga memenuhi syarat sebagai batuan induk. Selain itu, anomali radiometri dan anomali kadar uranium terdapat pada Formasi Bobong. Data anomali tersebut semakin menguatkan bahwa Formasi Bobong sangat potensial sebagai batuan induk uranium. Presipitan utama untuk mineralisasi uranium tipe batupasir adalah material karbon dan pirit. Lapisan batubara (Gambar 8) dan pirit [27] terdapat di batupasir Formasi Bobong sehingga memenuhi kriteria sebagai presipitan.

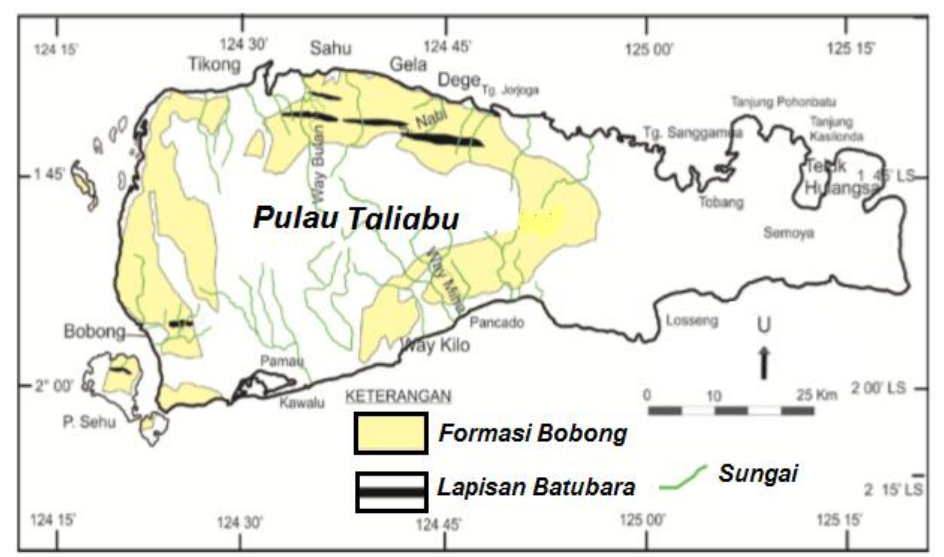

Gambar 8. Peta penyebaran lapisan batubara di Pulau Taliabu [27]. 


\section{KESIMPULAN DAN SARAN}

Berdasarkan data geologi, radiometri, kadar uranium batuan, serta kadar uranium endapan sungai dan konsentrat dulang yang telah dibahas pada bab-bab sebelumnya maka disimpulkan bahwa di Pulau Taliabu berpotensi terbentuk mineralisasi uranium tipe batupasir. Granit Banggai diperkirakan sebagai batuan sumber uranium, batupasir Formasi Bobong sebagai batuan induk, dan batubara serta pirit sebagai presipitan. Daerah potensial uranium terdapat di sekitar penyebaran batuan Formasi Bobong. Untuk mengetahui lebih jelas keterdapatan mineralisasi uranium maka disarankan dilakukan eksplorasi detil di Pulau Taliabu yang difokuskan di wilayah sekitar Formasi Bobong.

\section{UCAPAN TERIMA KASIH}

Penulis ingin menyampaikan terimakasih kepada Bapak Ir. Agus Sumaryanto, MSM selaku Kepala Pusat Teknologi Bahan Galian Nuklir yang telah mengijinkan penulis untuk mengkaji keterdapatan mineralisasi uranium di Pulau Taliabu dalam rangka pencarian daerah baru untuk eksplorasi uranium di masa mendatang. Penulis juga ingin menyampaikan terimakasih kepada teman-teman di bidang eksplorasi yang telah meluangkan waktu di sela-sela kesibukan untuk berdiskusi selama kajian ini berlangsung hingga selesai.

\section{DAFTAR PUSTAKA}

[1] R. P. Koesoemadinata and S. Sastrawiharjo, "Uranium Prospect in Tertiary Sediments Sibolga Area, North Sumatra," in Technical Committee Meeting on Uranium Deposits in Asia and the Pasific, Geological and Exploration, IAEA BATAN, 1985.

[2] B. Soetopo, "Studi Geologi dan Mineralisasi U Sektor Ririt, Amel dan Tiga Dara, Kalan, Kalimantan Barat," Eksplorium, vol. 30, no. 151, 2009.
[3] L. Subiantoro, P. Widito, and A. Marzuki, "Sintesis Geologi dan Mineralisasi U di Sektor Tanah Merah, Kalan, Kalimantan Barat," Eksplorium, vol. 28, no. 143, 2007.

[4] Ngadenin, I. G. Sukadana, A. G. Muhammad, and Suripto, "Inventarisasi Potensi Sumber Daya Uranium Daerah Kawat, Mahakam Hulu, Kalimantan Timur Tahapan Prospeksi Detil," Eksplorium, vol. 32, no. 2, 2011.

[5] I. G. Sukadana and F. D. Indrastomo, "Geologi dan Keterdapatan U di Sektor Paluq, Mahakam Hulu, Kalimantan Timur," Eksplorium, vol. 31, no. $154,2010$.

[6] I. G. Sukadana, "Geologi dan Mineralisasi U Sektor Nyaan, Mahakam Hulu, Kalimantan Timur," Eksplorium, vol. 33, no. 2, 2012.

[7] Ngadenin, I. G. Sukadana, F. D. Indrastomo, R. Iswanto, Tukijo, and U. Sarip, "Inventarisasi Potensi Sumberdaya Uranium di Mamuju, Sulawesi Barat Tahapan Prospeksi Pendahuluan," Jakarta, 2014.

[8] F. P. Sagala, "Survei Geologi Daerah Hulu Way Samang, Lampung," Jakarta, 1972.

[9] T. O. Simanjuntak and A. J. Barber, "Contrasting Tectonic Styles in the Neogene Orogenic Belts of Indonesia," Tecton. Evol. Southeast Asia, vol. 106h, 1996.

[10] M. G. Audley-Charles, D. J. Carter, and J. S. Milsom, "Tectonic Development of Eastern Indonesia in Relation to Gondwanaland Dispersal," Nature, vol. 239, pp. 35-39, 1972.

[11] R. Hall, "Late Jurassic-Cenozoic Reconstructions of the Indonesian Region and the Indian Ocean," Tectonophysics, vol. 570-571, pp. 1-41, 2012.

[12] G. D. McKenzie, Gondwana Six: Stratigraphy, Sedimentology and Paleontology. Washington DC: American Geophysical Union, 1997.

[13] T. H. Torsvik and L. R. M. Cocks, "Gondwana from Top to Base in Space and Time," Gondwana Res., vol. 24, no. 3-4, pp. 999-1030, 2013.

[14] E. Suess, Das Antlitz der Erde. Leipzig, Germany: G. Freytag, 1885.

[15] D. Cole, "A Review of Uranium Deposits in the Karoo Supergroup of South Africa," in AAPG International Conference and Exhibition, 2008.

[16] Y. A. Murkute and S. P. Joshi, "Environment of Geological Setting for Uranium Mineralization and Geochemical Exploration with Review from Central India," Int. J. Geol. Earth Environ. Sci., 
vol. 5, no. 3, pp. 108-117, 2015.

[17] A. D. Mckay and Y. Miezitis, “Australia's URANIUM Resources, Geology and Development of Deposits," Canberra, 2007.

[18] F. J. Dahlkamp, Uranium Deposits of the World: USA and Latin America. Berlin Heidelberg: Springer-Verlag, 2010.

[19] M. Cuney, "Supercontinents Cycle Through Time and Formation of Large Intracontinental Sedimentary Basin, Previliged Host of Sandstone Related Uranium Deposits," in Technical Meeting on Uranium Deposits Formed in the Gondwana Supercontinent: The Importance of the Gondwana, Karoo, Parana and Similar Sedimentary Basins, 2015.

[20] H. Tulsidas, "Uranium Potential in the Gondwanas: Overview of the Tecnonic Magmatic Controls," in Technical Meeting on Uranium Deposits Formed in the Gondwana Supercontinent: The Importance of the Gondwana, Karoo, Parana and Similar Sedimentary Basins, 2015.

[21] P. Bruneton, "Uranium Depopsits during the Gondwana System," 2015.

[22] J. B. Supandjono and E. Haryono, Peta Geologi Lembar Banggai, Sulawesi-Maluku Skala 1:250.000. Bandung: Pusat Penelitian dan Pengembangan Geologi, 1993.

[23] Surono and D. Sukarna, Peta Geologi Lembar Sanana, Maluku Skala 1: 250.000. Bandung: Pusat Penelitian dan Pengembangan Geologi, 1993.

[24] F. Ferdian, R. Hall, and I. Watkinson, "A Structural Re-Evaluation Of The North BanggaiSula Area, Eastern Indonesia," in Proceedings, Indonesian Petroleum Association Thirty-Fourth
Annual Convention \& Exhibition, 2010.

[25] R. Sukamto, "Geologi Daerah Kepulauan Banggai dan Sula," Geol. Indones., vol. 2, no. 3, pp. 23-28.

[26] R. Sukamto, "The Structure of Sulawesi in the Light of Plate Tectonics," in Regional Conference on Geology and Mineral Resources of Southeast Asia, 1975.

[27] Kusnama, "Fasies dan Lingkungan Pengendapan Formasi Bobong Berumur Jura sebagai Pembawa Lapisan Batubara di Taliabu, Kepulauan SananaSula, Maluku Utara," J. Geol. Indones., vol. 3, no. 3, pp. 161-173, 2008.

[28] G. Bizon, J. J. Bizon, and C. Muller, "Result Stratigraphiques (Foraminiferes et Nanoplancton) des Echantillons Preveles en Indonesie dans I'Archipel de Sula et de Sulawesi (Celebes)," 1982.

[29] D. Soetarno, Paimin, and P. Sularto, "Prospeksi Pendahuluan Daerah Eksplorasi Indonesia Timur Kepulauan Sula,” Jakarta, 1982.

[30] Robert William Boyle, Geochemical Prospecting for Thorium and Uranium Deposits. Amsterdam: Elsevier Science Ltd, 1982.

[31] IAEA, World Distribution of Uranium Deposits (UDEPO) with Uranium Deposit Classification. Vienna: International Atomic Energy Agency, 2014

[32] B. Soetopo, "Studi Mikroskopis Mineralisasi Uranium Daerah Mentawa, Kalimantan Tengah," Eksplorium, vol. 31, no. 153, 2010. 